\title{
The Opinions of Teachers About the Innovation Level of Their Schools*
}

\author{
Hüseyin Aslan ${ }^{1}$, Fatma Kesik ${ }^{1}$, Cevat Elma ${ }^{1}$ \\ ${ }^{1}$ Ondokuz Mayis University, Educational Administration, Turkey \\ Correspondence: Fatma Kesik, Ministry of National Education, Educational Administration, Turkey.
}

Received: March 6, 2018

Accepted: April 10, $2018 \quad$ Online Published: May 4, 2018

doi:10.11114/jets.v6i6.3072

URL: https://doi.org/10.11114/jets.v6i6.3072

\begin{abstract}
This study aims to determine the opinions of teachers about the innovation level of their schools. The sample of this research includes 471 teachers working in primary and secondary schools in Sinop, a city in Turkey. "Innovative School Scale" developed by Aslan and Kesik (2017) was used in order to collect data in this study. Percentage, frequency, mean, standard deviation, T-test and one-way ANOVA were performed to determine teachers' opinions about the innovation level of their schools according to the demographic variables. The findings show that the opinions of teachers about the innovation level of their schools are quite high with a level of "often" in the dimensions of innovative atmosphere, administrative support and the overall scale and with a level of "sometimes" in the organizational impediments. While the teachers' opinions indicate no significant differences regarding their genders, they show significant differences regarding their subject areas, years of teaching experience and teaching level of school. According to findings, branch teachers, teachers working in secondary schools and teachers having 21 or more years of teaching experience were found to have a higher level of opinions about the innovation level of their schools. The findings and suggestions obtained by the results are expected to contribute to the discussions and literature about increasing innovation level of schools.
\end{abstract}

Keywords: innovative school, innovation, teacher

\section{Introduction}

Innovation which is frequently used with the concepts of change and creativity is defined as "the successful implementation of creative ideas within an organization" (Amabile, Conti, Coon, Lazenby \& Herron 1996: 2) and "a process of developing and implementing a new idea" (Van de Ven \& Angle, 1989: 12). According to Seymour and Fife (1988), while the innovation, as a tool to exploit change, might be a distinctive technology, it might be a new organizational structure or a new instructional method brought into the educational system. In today's world which the change is unavoidable, the subject of innovation has been a matter of research for a long time (Damanpour \& Evan, 1984; Van de Ven \& Rogers, 1988; Anderson \& King, 1993; Amabile et al, 1996; Montes, Moreno \& Fernandez, 2004; Scot, Bruce \& Reginald 2005; Mclean, 2005; Moolenaar, Daly \& Sleegers, 2010). However, most of the researches have been concentrated on the business and industrial organizations and the field of education has been undermined for a long time. Although no other field has been more subject to innovation than education (Hockley, 2009) and the schools are the basic elements of the innovation process, they can be accepted as weak about the transformation and sharing of information related to the innovation (Fullan, 2002). Within a context of change and innovation in the field of education, the effectiveness of schools can be provided with a creative environment encouraging teachers to take risks, improve their professionalism, have responsibility and use initiative instead of a traditional hierarchical model (Edwards, Green \& Lyons, 2002).

Innovative schools promoting such kinds of characteristics as democratic, community oriented approaches to learning and teaching and student centered have gained some national and international recognition (Armstrong, Henson \& Savage, 1997). The EU has given a special importance to the role of education to carry out the intended innovations on the Lisbon Agenda (COM, 2006) and thus the innovative schools having the characteristics above have come into prominence all around the world. For the innovation to take place in schools, an innovative climate including innovative structures, leadership and staff have utmost importance (Watt, 2002). Considering the climate as a cultural force,

\footnotetext{
${ }^{*}$ This study is an extended form of the conference paper presented at the $26^{\text {th }}$ International Education Sciences Conference (ICES) on April, 20-23, 2017.
} 
Seymour and Fife (1988) evaluated the innovation level of an organization with the individuals supporting change. Similarly, there are some other researchers suggesting innovation has a close relationship with the social relationships within and across systems (Tenkasi \& Chesmore, 2003; McGrath \& Krackhardt, 2003) Within this context, innovative climate can be defined as the shared perceptions of organizational members regarding the procedures, practices and behaviors promoting the generation of new knowledge and practices (Moolenaar, Daly \& Sleegers, 2010). The importance of an innovative climate to promote the generation, adoption, and implementation of new knowledge, practices and innovative behavior has been adressed in various studies (Ekvall, 1996; Mclean, 2005; Panuwatwanich, Stewart \& Mohamed, 2008). Aspects such as openness in communication, establishing networks among individuals within the organization and institutions outside (Sharma, 2001), supporting ideas, risk taking, trust, intrinsic movement, intellectual orientation and freedom (Mumford, Scott \& Gaddis, 2002) have been the particular motives for an innovative organization. An innovative climate increases the members' motivation by encouraging autonomy and risk taking so it enables them to be more willing for innovative behaviour (Jung, Chow \& Wu, 2003). According to Heck and Marcoulides (1996), schools encouraging innovation and risk taking, fostering teacher participation in decision-making and providing time for collaboration were found to be more efficient. Similarly, Watt (2002) asserted that innovative schools having an entrepreneurial and risk taking spirit fostered collaborative approaches to learning and innovation. Taking the innovative climate's relation with with teachers' knowledge creation, Song, Kim, Chai \& Bae (2014) suggest that an innovative school climate has a positive impact on teachers' knowledge sharing and work engagement and influences teachers' knowledge creation practices in a positive way.

As an important determinant of an innovative school climate, there have been various studies regarding the impact of structures and procedures on an organization's adoption of innovation (Zaltman, Duncan \& Holbek, 1973; Mercer, 1983; DeCanio, Dibble \& Amir-Atefi, 2000; Chiaroni, Chiesa \& Frattini, 2011; Lee, Min \& Lee, 2016). While, the organizations having low centralization were found to provide for more flexibility and foster a participative decision making process paving the way for the generation of new ideas (Daly, 2009); in organizations with a strongly centralized network, the members may perceive limited impact on the decision making process as the decisions are shared among only a few influential people within the organization (Moolenaar, Sleegers, Daly, 2011). In the innovative schools, "the organizational structure was constructed in a way to allow for the necessary free, fast and unimpeded flow of knowledge required for innovation with the individuals and groups that have significant and meaningful input into decision-making process" (Dibbon \& Pollock, 2007: 10). Similarly, Watt (2002:10), describes the structures and processes of innovative schools as "flexible, allowing for sharing of knowledge and the ability to work in teams with less hierarchy than normal schools".

Leadership, as another determinant of the innovative school climate, plays an important role to enable the required conditions and climate for innovations to happen (Siegel \& Kaemmerer 1978; Bass \& Riggio, 2006; Prew, 2007; Sağnak, 2012). According to Watt (2002), a successful innovation requires leaders who have a commitment for change and a clear vision and are enthusiastic about taking risks and leading. As leadership behavior has an impact on innovative climate, the type of leadership is an important factor which influences organizational innovation (Jung et al., 2003). According to Anderson and King (1993), different stages of innovation require different styles of leadership at different points of time in the process and multiple leadership approaches are suitable for each innovation; for example for the initiation phase a nurturing type of leadership and for the implementation phase a championing type, etc. There is an increasing number of researches suggesting that innovation-supportive climates may be facilitated or constrained by leadership behavior (Mumford, Scott, Gaddis, \& Strange, 2002) paving the way for different leadership styles in the innovation process. Some researchers advocate the transformational leadership for the effectiveness of the innovation process (Jung, et al., 2003; Sarros, Cooper \& Santara; 2008; García-Morales, Jiménez-Barrionuevo \& Gutiérrez-Gutiérrez, 2012) and some others argue for a transactional leadership (Jung, 2001; Jansen, Vera \& Crossan, 2009). While transformational leadership improves the innovative climate of an organization by providing a vision and setting clear goals; individual consideration -confidence in individuals' innovative capacities-; intellectual stimulation (Moolenar, Daly \& Sleegers, 2010); transactional leadership is associated with exploitative innovation and facilitates improving and extending existing knowledge (Jansen, Vera \& Crossan, 2009). Anderson and King (1991) argued that such points as encouraging individual attempts of staff, clarifying their responsibilities, providing a clear feedback about their performance, laying emphasis on human resources and task orientation and demonstrating trust in the members of organization. According to Siegel and Kaemmerer (1978), leadership is one of the most important factors that determine the innovative climate of schools and "the principal is the key figure in determining the take-up of an innovation in a school" (Prew, 2007: 458). School effectiveness and innovation literature shows that the principals influence the probability of change on a large scale and so they should be equipped with leadership characteristics which facilitate change as initiators (Fullan, 2001). Also, they should have the attitudes of giving importance to the innovation and risk taking (Harris, Day, Hopkins, Hadfield, Hargreaves \& Chapman, 2003). As the leaders of the school, the principals should have a clear vision about where to take their school, have a commitment to change and support 
risk taking (Watt, 2002). They should also encourage the school's innovative climate by developing nurturing relationships and providing support (Shalley \&Gilson, 2004) and respecting the different identities of individual teachers (Ketelaar, Beijaard, Boshuizen \& Den Brok 2012 ).

Being the key actors of innovation, people, staff, have a vital role in the success of an innovation (Zaltman \& Duncan, 1977; Fullan, 1991; Watt, 2002). According to Daft and Becker (1978: 154), "innovation does not require free resources so much as it requires people to push innovation". The innovation process depends largely on the knowledge, skills, experiences and concerns of the individuals and groups involved in the process (Hall \& Hord, 1987). While some people in organizations adopt innovations eagerly and unhesitatingly as innovators; the others behave more cautiously, reluctantly and under some circumstances may reject the innovations completely as resistors (Sharma, 2001). So, it's important to include all individuals within the organization as innovators to achieve the innovations and create the necessary conditions for an innovative climate. Watt (2002: 10) describes the attributes of people in a creative and innovative school like: "creativity, continuous improvement skills, implementation abilities, risk taking capacities, and relationship building skills". A study by Geijsel, Berg and Sleegers (1999) about the innovative capacity of schools suggest that there is a relationship between a school's innovative climate and expectations and satisfaction of teachers related to the degree of collaboration. While the teachers working in schools with a strong innovative climate have higher expectations of collaboration; the teachers working in low innovative climate schools have fewer expectations of collaboration. In an innovative school, collaboration is given utmost importance and teachers work together to generate new ideas, learn new skills, and build up programs (Watt, 2002). Moolenaar, Sleegers and Daly (2011) argued that for an innovative climate to occur, dense social networks among teachers were identified as helpful since social interactions enable teachers to participate in decision-making process more which give rise the opportunities to create new knowledge and practices which strengthen the innovative climate of schools. The more tied teachers were to the work related and personal advice, the more they thought their schools have an innovative climate. According to a research done by Ketelaar, Beijaard, Boshuizen and Den Brok (2012) the correspondance of teachers' frame of references with the frame of reference of the innovation and collaboration among teachers were found important in teachers' positioning themselves towards an educational innovation. An educational innovation introduced by the government doesn't always evoke resistance only if it corresponds with the teachers' frame of references and teachers feel ownership regarding the innovation. Also, collaboration may help to prevent teachers from wandering towards the dark side of ownership, sense-making and agency, and ending up on an 'island' within their school where nobody can reach them anymore (Ketelaar, et. al., 2012 :25)

In Turkey there have been several initiatives to introduce innovation in education such as extending the duration of compulsory education to 12 years; Movement of Enhancing Opportunities and Improving Technology (Fatih Project), acceptance of a student centered and constructivist curriculum instead of a teacher centered one, etc. However, all these innovation attempts have mostly been in the system level and not been addressed to school specific issues such as creating a shared vision, opportunities for an innovative climate in schools due to the centralized administration of Turkish education system and participation of teachers in the decision making processes in limited level. Principals' not exhibiting change leadership roles (Fullan, 2001), becoming more focused on the technical elements of the reform (Moolenaar, Daly \& Sleegers, 2010) and teachers' not involving in the design of educational innovations mostly (Van Veen \& Sleegers, 2006) may have influenced the reactions of the teachers to the implementation of innovations. It's evident that while most of the policies related to improvement are concentrated on the technical elements of reform and focus on superficial aspects of schools and such issues as program fidelity, rigid curriculum, and prescriptive approaches (Daly, 2009); they undermine the main determinants of an innovative school like culture and climate. "Without a direct and primary focus on changes in organizational factors it is unlikely that [single innovations or specific projects] will have much of a reform impact, and whatever impact there is will be short lived ... school improvement efforts which ignore these deeper organizational conditions are 'doomed to tinkering'... Strategies are needed that more directly address the culture of the organization" (Fullan, 1988: 28).

\subsection{Literature Review}

As for the studies about the concept of innovation in education organizations, it is observed that the concept is mostly addressed within the framework of change and creativity. The studies carried out abroad about the concept have mostly centered around the innovation and innovation process in education and schools (Corwin, 1975; Watt, 2002; Pollock, 2008). Similarly, the studies in Turkey gather around organizational change and innovation (Özdemir, 1995; Özdemir \& Cemaloğlu, 1999; Aslaner, 2010; Hatipler, 2014), the need for innovation in elementary schools (İnand1, 1999; Beycioğlu, 2004), the drawbacks to innovation in education (Karip, 1997; Cemaloğlu, 1999; Taş, 2007; Gülşen \& Gökyer, 2010). The number of studies examining the opinions of teachers in primary and secondary schools and the relationships of these opinions with some demographic variables are quite limited in literature. However, some studies determining the relationships of some variables with motivation, communication, culture and climate may give hints 
about the innovation level of schools. Therefore, it can be asserted that in addition to the importance of attributes of people to carry out the innovations in schools, the demographic characters of them and the teaching level of the school they work may affect the innovative climate of schools. It has been found out in several studies that males have more positive opinions about the change and innovation processes in schools (Çakır, 2009; Korkut, 2009; Demirtaş, 2010; Canlı, Demirtaş \&Özer, 2015), resist less to change and innovation (Aydın \& Şahin, 2016) and tend to take more risks (Kayasandik, 2017). Although gender roles differ among societies, the permanent truth is that the women are only of secondary place compared to men (Yılmaz \& Sünbül, 2009); therefore it's expected that the women are less entrepreneurial as a result of a more oppressive and submissive method of child raising compared to men (Ar1, 1989). Similarly, teachers who have more teaching experience have been found more innovation friendly compared to the less experienced ones in most of studies (Glantz, 1998; Tanıt, 2003; Beycioğlu, 2004; Özata, 2007; Kondakçı, Zayim ve Çalışkan, 2010; Demirtaş, 2012; Kayasandık, 2017). Although the experienced teachers are generally expected to resist change as a result of their established routines for classroom behavior, working for long in the same organization and bureaucratic socialization (Palmer, 1993) and get involved in school reform initiatives reluctantly and mistrustfully (Foster, 1993), it is the more experienced teachers who welcome change and innovation more in most of the studies. This can be explained with the experienced teachers' finding more strength in themselves to overcome the organizational and bureaucratic obstacles to generate innovations. Teachers' subject areas may also be considered as an important determinant of their attitude and perceptions about change and innovation. It has been identified in several studies that class teachers, in other words teacher working in primary schools, have more positive opinions about the culture of their schools ( Çelik, 2004; Arslan, Kuru \& Satıcı, 2005; Kondakçı, Zayim \&Çalışkan, 2010) and therefore more innovation oriented (Maslowski, 2001). As class teachers spend more time in school, they contribute to a school culture which is open to communication more (Çelik, 2004) Therefore, it's expected that a strong school culture is more open to change and innovation. However, class teachers' not having as many opportunities as subject teachers (English, Maths, Science, Social studies, Music, Art, Physical education, etc) to interact with the teachers from other disciplines and to experience different practices may have a negative effect on their attitudes towards change and innovation. In their studies Kurşunoğlu and Tanrı̈ğen (2006) found out that subject teachers had more positive attitudes towards change and supported change more. Therefore, identifying the opinions of teachers about the innovation level of their schools according to some variables which are estimated to have an important effect on the teachers' perceptions about the innovation in schools is considered to contribute to the related literature to a great extent as the teachers have a great influence on education system both quantitatively and qualitatively. This study aims to identify the opinions of teachers about the innovation level of their schools. So, it seeks to answer the following associated questions:

1. What are the opinions of teachers about the innovation level of their schools?

2. Is there a significant difference between the opinions of teachers about the innovation level of their school and their demographic characteristics such as gender, subject area, years of teaching experience and the teaching level of school?

\section{Method}

\subsection{Research Model}

In this research a descriptive survey which deals with the current phenomena in terms of changing conditions, processes, practices and relationships was used. Surveying model is a research approach aiming to describe a situation which has existed both in the past and at the present time as it already is (Karasar, 2007: 77) and it is related both with the individuals' characteristics and the features of the whole phenomenon by offering information to interpret and solve problems (Salaria, 2012).

\subsection{Participants and Procedures}

The population of the study comprised of 1411 teachers working in public primary and secondary schools in the city of Sinop, a city in Turkey, during the 2016-2017 school year. The sample in this study was selected with random sampling method which give the whole units of the population the chance of being selected and 471 teachers participating voluntarily and anonymously in the study constituted the sample of the study.

Out of these 471 teachers, 251 were females and 220 were males. The sample comprised of 170 classroom teachers (teachers working in primary schools) and 301 subject teachers (English, Math, Science, Social studies, Music, Art, Physical education) Also, 143 teachers were working in primary schools and 262 of them were working in secondary schools. Lastly, 140 teachers had 1-10 years of teaching experience, 164 of them had 11-20 years of teaching experience and 167 of them had 21 or more years of teaching experience.

\subsection{Instruments}

As data collection instrument, "Innovative School Scale" (ISS) developed by Aslan and Kesik (2016) was used. The survey 
items were scored on a 5 point Likert-rating scale on frequency of activity, ranging from 1 representing 'never' to 5 'always'. Before carrying out the analysis, the items belonging to the subscale of Organizational Impediments were reverse scored. The scale has three sub-dimensions called as "Innovative Atmosphere, Administrative Support and Organizational Impediments" and 19 items. The subscale of Innovative Atmosphere includes such items as "There is a climate encouraging innovation", "The trust between the school principal and teachers is high", etc. Administrative Support subscale includes such items as "Teachers can make innovative decisions", "Teamwork is supported to enable innovation to occur", etc. Organizational Impediments subscale includes such items as "School members are afraid of taking risks", "Innovation isn't a fundamental organizational aim. These all sub dimensions have been explaining .62.70 of total variance and factor loadings of all items range from .86 to .52 . The results of the confirmatory factor analysis are shown in the following table.

Table 1. Fit index values regarding the confirmatory factor analysis of the Innovative School Scale

\begin{tabular}{ll}
\hline Fit Index & Coefficient \\
\hline$\chi^{2}$ & 360.38 \\
$\mathrm{Sd}$ & 146 \\
$\chi^{2} / \mathrm{sd}$ & 2.46 \\
Goodness of Fit Index (GFI) & 0.90 \\
Adjusted Goodness of Fit Index (AGFI) & 0.87 \\
Non-Normed Fit Index (NNFI) & 0.97 \\
Normed Fit Index (NFI) & 0.95 \\
Comparative Fit Index (CFI) & 0.97 \\
Root Mean Square Error of Approximation (RMSEA) & 0.055 \\
Standardized Root Mean Square Residual (SRMR) & 0.069
\end{tabular}

According to Table 2, it may be asserted that the three factors model of the scale has construct validity in a reasonable level and the three factors structure of the scale were confirmed.

As for the reliability analysis, Cronbach Alfa analysis was carried out and the reliability coefficient for the Innovative School Scale instrument as a whole was found 0.85 , indicating a strong internal consistency. The reliability coefficients for the three subscales were as follows: 0.91 for Administrative Support, 0.90 for Innovative Atmosphere and 0.79 for organizational impediments.

\subsection{Data Collection and Analysis of Data}

Ethical issues have been given utmost importance at all stages of this study. Legal permission was obtained from the Ministry of National Education and the participants were chosen among the volunteers. In data analysis which SPSS 15.0 for Windows was used, the mean, standard deviation, and frequency were calculated, and t-test and ANOVA tests were performed. In cases which significant differences were identified, Tukey was used and 0.05 significance level was grounded to test the differences among the group average points. In order to control the assumption of normality of scale scores of teachers, skewness and curtosis coefficients were calculated and the skewness coefficient was found as -.252 and the curtosis coefficient was found as .242. As the skewness and curtosis coefficients of the scale score within the range of \pm 1 , this result revealed that the scores didn't show deviation and the data displayed normal distribution. (Büyüköztürk, Çokluk \& Şekercioğlu, 2012). Also, Levene Test for Equality of Variances was made to identify whether the variances are equal or not and the significance level was found above .05 and the variances were equal. Also, the significance level for the variable of teaching experience was found above $.05\left(\mathrm{~F}_{(\mathrm{YO})}=2.152\right.$, df1=2, df2=468, $\left.\mathrm{p}>0.05\right)$.

While interpreting the average points, the score ranges for the Innovative School Scale are as follows:

1-1.80: "Never"

1.81-2.60: "Seldom"

2.61-3.40: "Sometimes"

3.41-4.20: "Often"

4.21-5.00: "Always"

\section{Findings}

In this part of the study, research questions were taken into consideration respectively and the results were analyzed in accordance with the tables. 


\subsection{Teachers' Opinions About the Innovation Level of Their Schools}

Results of the analysis carried out to identify the opinions of teachers about the innovation level of their schools are shown in the following table.

Table 3. Teachers' opinions about the innovation level of their schools

\begin{tabular}{llll}
\hline Dimension & $\mathrm{N}$ & $\mathrm{X}$ & $\mathrm{Ss}$ \\
\hline Innovative Atmosphere & 471 & 3,82 & 0,86 \\
\hline Administrative Support & 471 & 3,48 & 0,53 \\
\hline Organizational Impediments & 471 & 3,03 & 0,61 \\
\hline Total & 471 & 3,42 & 0,47 \\
\hline
\end{tabular}

According to Table 1, while the mean for innovative atmosphere is 3.82 ; it is 3.48 for administrative support and 3.42 for overall scale with the level of "often" and the mean for organizational impediments is 3.03 with the level of "sometimes". This result suggests that although the teachers sometimes encounter some organizational impediments, they have often positive opinions about the innovative atmosphere of their schools; they take enough administrative support to make their schools more innovative and thus they often find their school's atmosphere innovative.

\subsection{Teachers' Opinions About the Innovation Level of Their Schools According to Their Gender}

The findings regarding the analyses carried out to determine whether the teachers' opinions about the innovation level of their schools show difference according to their genders are shown in Table 2.

Table 2. Teachers' opinions about the innovation level of their schools according to their gender

\begin{tabular}{|c|c|c|c|c|c|c|c|}
\hline Dimension & Gender & $\mathrm{N}$ & $\mathrm{X}$ & Ss & $\mathrm{Sd}$ & $\mathrm{T}$ & $\mathrm{P}$ \\
\hline \multirow{2}{*}{ Innovative Atmosphere } & Female & 251 & 3,79 & 0,85 & 469 & 921 & ,358 \\
\hline & Male & 220 & 3,86 & 0,87 & & & \\
\hline \multirow{2}{*}{ Administrative Support } & Female & 251 & 3,46 & 0,65 & 469 & 693 & ,489 \\
\hline & Male & 220 & 3,51 & 0,58 & & & \\
\hline \multirow{2}{*}{ Organizational Impediments } & Female & 251 & 2,97 & 0,59 & 469 & 2,019 &, $044^{*}$ \\
\hline & Male & 220 & 3,09 & 0,63 & & & \\
\hline \multirow[t]{2}{*}{ Total } & Female & 251 & 3,41 & 0,49 & 469 & 1,658 & ,098 \\
\hline & Male & 220 & 3,48 & 0,50 & & & \\
\hline
\end{tabular}

$* \mathrm{p}<0.05$

Table 2 reveals that while there aren't any significant differences between the opinions of male and female teachers in the dimensions of innovative atmosphere $\left[\mathrm{t}_{(469)}=.921, \mathrm{P}>0.05\right]$, administrative support $\left[\mathrm{t}_{(469)}=.693, \mathrm{P}>0.05\right]$ and the overall scale $\left[\mathrm{t}_{(469)}=1,658, \mathrm{P}>0.05\right]$, there is a significant difference between the opinions of teachers in the dimension of organizational impediments. It has been determined that male teachers have higher points compared to female teachers in the dimension of organizational impediments. Within this context, it can be asserted that male teachers have more positive opinions in such issues as risk taking, being courageous towards the unknown, welcoming innovations with less fear, less anxiety, attempting to change the current circumstances and thus are better at overcoming the obstacles towards innovation in their schools.

\subsection{Teachers'opinions about the Innovation Level of Their Schools According to Their Subject Areas}

The findings regarding the analyses carried out to determine whether the teachers' opinions about the innovation level of their schools show difference according to their subject areas are shown in Table 3.

Table 3. Teachers' opinions about the innovation level of their schools according to their subject areas

\begin{tabular}{llllllll}
\hline Dimension & Subject Area & $\mathrm{N}$ & $\mathrm{X}$ & $\mathrm{Ss}$ & $\mathrm{Sd}$ & $\mathrm{T}$ & $\mathrm{P}$ \\
\hline \multirow{2}{*}{ Innovative Atmosphere } & Branch Teac. & 301 & 3,91 & 0,69 & 469 & 2,945 & \multirow{2}{*}{, $003^{*}$} \\
& Class Teac. & 170 & 3,67 & 1,07 & & \\
\hline \multirow{2}{*}{ Administrative Support } & Branch Teac. & 301 & 3,50 & 0,49 & 469 & 1,063 & \multirow{2}{*}{, 288} \\
& Class Teac. & 170 & 3,45 & 0,59 & & & \\
\hline \multirow{2}{*}{ Organizational Impediments } & Branch Teac. & 301 & 3,07 & 0,58 & 469 & 2,103 & \multirow{2}{*}{, $036^{*}$} \\
& Class Teac. & 170 & 2,95 & 0,64 & & \\
\hline \multirow{2}{*}{ Total } & Branch Teac. & 301 & 3,49 & 0,35 & 469 & 3,031 & \multirow{2}{*}{, $003^{*}$} \\
& Class Teac. & 170 & 3,36 & 0,60 & & \\
\hline
\end{tabular}

$* \mathrm{p}<0.05$

As shown in Table 3, while there aren't any significant differences between the opinions of branch and class teachers in 
the dimension of administrative support $\left[\mathrm{t}_{(469)}=1.063, \mathrm{P}>0.05\right]$, there is a significant difference between the opinions of teachers in the dimensions of innovative atmosphere $\left[\mathrm{t}_{(469)}=2.945, \mathrm{P}<0.05\right]$, organizational impediments $\left[\mathrm{t}_{(469)}=2.103\right.$, $\mathrm{P}<0.05]$ and the overall scale $\left[\mathrm{t}_{(469)}=3.031, \mathrm{P}<0.05\right]$ and branch teachers have higher scores than class teachers. Therefore, it can be asserted that branch teachers find the atmosphere of their schools more innovative, have more enthusiastic about overcoming the organizational impediments and therefore have more positive ideas about the innovation level of their schools compared to class teachers.

\subsection{Teachers' Opinions About the Innovation Level of Their Schools According to the Teaching Level of Schools}

The findings regarding the analyses carried out to determine whether the teachers' opinions about the innovation level of their schools vary according to the teaching level of school are revealed in Table 4.

Table 4. Teachers' opinions about the innovation level of their schools according to the teaching level of school

\begin{tabular}{|c|c|c|c|c|c|c|c|}
\hline Dimension & $\begin{array}{l}\text { Teaching level of } \\
\text { School }\end{array}$ & $\mathrm{N}$ & $X$ & Ss & sd & $\mathrm{t}$ & $\mathrm{P}$ \\
\hline \multirow{2}{*}{ Innovative Atmosphere } & Primary & 143 & 3,64 & 1,13 & \multirow[t]{2}{*}{469} & \multirow[t]{2}{*}{2,766} & \multirow[t]{2}{*}{, $006^{*}$} \\
\hline & Secondary & 262 & 3,89 & 0,67 & & & \\
\hline \multirow{2}{*}{ Administrative Support } & Primary & 143 & 3,42 & 0,61 & \multirow[t]{2}{*}{469} & \multirow[t]{2}{*}{1,576} & \multirow[t]{2}{*}{, 116} \\
\hline & Secondary & 262 & 3,51 & 0,48 & & & \\
\hline \multirow{2}{*}{$\begin{array}{l}\text { Organizational } \\
\text { Impediments }\end{array}$} & Primary & 143 & 2,94 & 0,66 & \multirow[t]{2}{*}{469} & \multirow[t]{2}{*}{2,517} & \multirow[t]{2}{*}{, $012 *$} \\
\hline & Secondary & 262 & 3.10 & 0,58 & & & \\
\hline \multirow[t]{2}{*}{ Total } & Primary & 143 & 3,34 & 0,64 & \multirow[t]{2}{*}{469} & \multirow[t]{2}{*}{3,258} & \multirow[t]{2}{*}{, $001 *$} \\
\hline & Secondary & 262 & 3,51 & 0,36 & & & \\
\hline
\end{tabular}

${ }^{*} \mathrm{p}<0.05$

As seen in Table 4, while there isn't a significant difference between the opinions of teachers working in primary and secondary schools in the dimension of administrative support $\left[\mathrm{t}_{(469)}=1.576, \mathrm{P}>0.05\right]$, there are significant differences between the opinions of teachers in the dimensions of innovative atmosphere $\left[\mathrm{t}_{(469)}=2.766, \mathrm{P}<0.05\right]$, organizational impediments $\left[\mathrm{t}_{(469)}=2.517, \mathrm{P}<0.05\right]$ and the overall scale $\left[\mathrm{t}_{(469)}=3.258, \mathrm{P}<0.05\right]$ and teachers working in secondary schools have higher scores about the innovation level of their school than teachers working in primary schools. Within this context, it can be claimed that teachers working in secondary schools have more positive opinions about the innovation level of their schools and feel fewer impediments to make their schools innovative compared to teachers working in primary schools.

\subsection{Teachers' Opinions About the Innovation Level of Their Schools According to Years of Teaching Experience}

The findings regarding the analyses carried out to determine whether the teachers' opinions about the innovation level of their schools show difference according to the years of their teaching experience are shown in Table 5.

Table 5. Teachers' opinions about the innovation level of their schools according to years of teaching experience

\begin{tabular}{|c|c|c|c|c|c|c|c|c|c|c|}
\hline Dimension & $\begin{array}{l}\text { Years of teaching } \\
\text { experience }\end{array}$ & $\mathrm{N}$ & $\mathrm{X}^{-}$ & Ss & $\begin{array}{l}\begin{array}{l}\text { Sum } \\
\text { squares }\end{array} \\
\end{array}$ & $\mathrm{Sd}$ & $\begin{array}{l}\text { Average of } \\
\text { the squares }\end{array}$ & F & $\mathrm{p}$ & Difference \\
\hline \multirow{4}{*}{$\begin{array}{l}\text { Innovative } \\
\text { Atmosphere }\end{array}$} & $1-10$ & 140 & 3,92 & 0,88 & 389,360 & 2 & 194,680 & 7,505 & ,001 & $1-2,2-3$ \\
\hline & $11-20$ & 164 & 3,62 & 0,94 & $12,140,097$ & 468 & 25,940 & & & \\
\hline & $21+$ & 167 & 3,95 & 0,70 & 12529,456 & 470 & & & & \\
\hline & Total & 471 & 3,82 & 0,86 & & & & & & \\
\hline \multirow{4}{*}{$\begin{array}{l}\text { Administrative } \\
\text { Support }\end{array}$} & $1-10$ & 140 & 3,46 & 0,55 & 183,307 & 2 & 91,653 & 6,720 & ,001 & $2-3$ \\
\hline & $11-20$ & 164 & 3,38 & 0,52 & 6382,812 & 468 & 13,638 & & & \\
\hline & $21+$ & 167 & 3,59 & 0,50 & 6566,119 & 470 & & & & \\
\hline & Total & 471 & 3,48 & 0,53 & & & & & & \\
\hline \multirow{4}{*}{$\begin{array}{l}\text { Organizational } \\
\text { Impediments }\end{array}$} & $1-10$ & 140 & 2,92 & 0,66 & 104,857 & 2 & 52,428 & 3,936 & 020 & $1-3$ \\
\hline & $11-20$ & 164 & 3,03 & 0,59 & 6233,173 & 468 & 13,319 & & & \\
\hline & $21+$ & 167 & 3,05 & 0,58 & 6338,030 & 470 & & & & \\
\hline & Total & 471 & 3,03 & 0,61 & & & & & & \\
\hline \multirow{4}{*}{ Total } & $1-10$ & 140 & 3,43 & 0,49 & 1325,149 & 2 & 662,574 & 8,628 & 000 & $2-3$ \\
\hline & $11-20$ & 164 & 3,34 & 0,50 & 35937,327 & 468 & 76,789 & & & \\
\hline & $21+$ & 167 & 3,55 & 0,38 & 37262,476 & 470 & & & & \\
\hline & Total & 471 & 3.45 & 0,46 & & & & & & \\
\hline
\end{tabular}

According to Table 5, it was found out that the opinions of teachers about the innovation level of their schools differed significantly according to their years of teaching experience in the dimensions of innovative atmosphere $\left[\mathrm{F}_{(2-468)}=7.505\right.$, 
$\mathrm{P}<0.05]$, administrative support $\left[\mathrm{F}_{(2-468)}=6.720, \mathrm{P}<0.05\right]$, organizational impediments $\left[\mathrm{F}_{(2-468)}=3.936, \mathrm{P}<0.05\right]$ and the overall scale $\left[\mathrm{F}_{(2-468)}=8.628, \mathrm{P}<0.05\right]$. Accordingly, teachers having 21 years or more teaching experience were found to have higher points about the innovation level of their schools compared to teachers having 1-10 and 11-20 years of teaching experience. In other words, it can be asserted that the experienced teachers find the atmosphere of their schools more innovative, feel the administrative support more and are better at overcoming bureaucratic and organizational obstacles towards innovation compared to teachers having less experience.

\section{Discussion and Suggestions}

As a result of this study aiming to identify the opinions of teachers about the innovation level of their schools, it was determined that teachers often found their schools' atmosphere innovative and they were often supported by the administration although they sometimes had problems to overcome organizational impediments towards innovation. It has been identified in various studies that an innovative climate has utmost importance in the realization of an innovation (Ekvall, 1996; Mclean, 2005; Panuwatwanich, Stewart \& Mohamed 2008). While factors such as the trust between the administrators and staff, shared objectives and vision, participative problem solving and decision making processes, supporting creativity and risk taking increase the innovation level of an organization, some organizational and bureaucratic impediments resulted from the structure of the organization and the personality of the staff inhibit the innovative process in an organization. The organizations having a climate which is open to innovation are better at implementing innovations compared to organizations having a less innovative climate (Van den Berg \& Sleegers, 1996; Geijsel, 2001). Within the context of education organizations, as the schools fostering innovation were found to be more effective (Heck \& Marcoulides, 1996), the findings of this study and getting similar results from the studies carried out by Hatipler (2014) and Aslaner (2010) as to the positive attitudes and opinions of teachers working in elementary schools towards innovation and change can be considered an important progress for the Turkish education system which is striving hard to improve schools because "the school improvement efforts are more likely to succeed in innovation-supportive climates"(Moolenaar, Daly \& Sleegers, 2010: 656). However, it must be bore in mind that for the development of such kind of an innovative atmosphere, the role of the administrators is undeniable. The innovative behaviours of the administrators such as supporting team work and cooperation, participative decision making, entrepreneurship of teachers and welcoming each diversity in the school atmosphere may be considered as a catalyzer of the innovation process in schools. According to Moolenar, Daly and Sleegers ( 2010: 655) "leaders who are able to develop shared vision and goals, attend to the social needs of individuals, and provide intellectual stimulation are perceived to support the fertile ground for innovation". Thus, it may be argued that leaders may foster innovative climate in schools by supporting, encouraging teachers and enriching relationships among teachers.

As to the demographic characteristics of teachers, it was found in our study that while teachers' gender didn't play an important role in the dimensions of innovative atmosphere, administrative support and the overall scale, male teachers had more positive opinions about the innovation level of their schools compared to female teachers in the dimension of organizational impediments. Accordingly, it can be argued that male teachers encounter fewer organizational impediments towards innovation. This may be related to that males have often a more advantegous status in organizations than the females. It's a well-known fact that the females often face lots of difficulties both as an administrator and teacher in schools as in all areas of social life.

Findings regarding the variables like teachers' subject areas and teaching level of school correspond to each other. It was identified in this study branch teachers and teachers working in secondary schools have more positive opinions about the innovation level of their schools compared to class teachers and teachers working in primary schools in the overall scale and all dimensions but the dimension of administrative support. This finding can be explained as a result of the branch teachers' having more opportunities to interact with the teachers from different branches, to experience different practices and thus being more open to innovation and change and contributing more to the innovation of schools. Similarly, in secondary schools, as an environment which paves the way for the teachers from different disciplines to come together and support innovation more by observing different experiences and practices, teachers were found to be more open to innovation. However, Maslowski (2001) revealed in his study that while secondary schools give more importance to performance and sustainability and are less susceptible to innovation, primary schools are more innovation focused and therefore open to innovation.

As an important variable, years of teaching experience demonstrated a significant difference in all dimensions and the whole scale itself in favor of teachers having 21 or more years of teaching experience. In parallel with this finding, Palmer (1993), Tanit (2003) and Moolenaar, Daly and Sleegers (2010) determined that experienced teachers are more flexible and open to change, thus more innovative supportive. So, it's expected that the experienced teachers find their schools more innovative and support innovative practices more. The findings of this study and similar findings revealed by Palmer (1993), Glantz (1998), Tanit (2003) and Moolenaar, Daly and Sleegers (2010) can be considered that the more experienced the teachers are, the more strength they find in themselves to overcome the organizational and bureaucratic obstacles to generate innovations. 
As mentioned above, the results of this study demonstrated positive teachers' opinions about the innovation level of their schools and this offers hope for the schools' improvement practices in Turkey. However, some concrete steps must be taken to maximize the innovative capacities of schools. Within this context, various practices to overcome organizational and bureaucratic impediments can be carried out. For an innovative atmosphere in schools, teachers can be encouraged more to try new practices and take risks; capacity building for the innovative practices can be improved. Not mentioned in this study specifically but as an important impediment to generate innovations, schools can be provided sufficient funding as most of the schools have difficulty in finding the necessary funding to carry out innovations. Also, for the organizations to be innovative as a team, each individual team member must be encouraged to share and discuss creative ideas and different point of views must be welcomed (Amabile et al., 1996).Thus, a distributed leadership style, paving way for a culture and climate giving voice to all school members, regarding varieties as something nourishing, improving a shared vision and thus fostering change and innovation, may be adopted in schools and school principals may be trained in this way.

As one of the rare studies carried out in Turkey within this area, there are a few limitations that must be referred to this study. Firstly, no matter how adequate the sample size for the analysis, the findings of this study reflect only a single city in Turkey and there may be problems related to the generalizability of the results. So, the same study can be carried out in a way of including high schools and if possible Turkey context. Secondly, limited demographic characteristics of participants were taken into account in this study. The study can be carried out in a way to include different variables such as school size, the socio-economic district where the school is situated, school type (public/private), etc. Also, only teachers' opinions about the innovation levels of schools were taken in this study; so this study may be enlarged by including school principals', students', even parents' opinions. Lastly, this is a quantitative study and just give the level of the teachers' opinions about the innovation level of their schools, not the knowledge why they think so and doesn't "highlight the differences that are not statistically significant (Patton, 1990) Therefore, a qualitative study or more preferably a mixed study probing the questions 'how innovative the school atmosphere is, in what ways the school principals support or don't support the innovative practices and what the organizational and bureaucratic impediments for the generation of innovations' is considered to contribute to the related literature a lot.

\section{References}

Amabile, T. M., Conti, R., Coon, H., Lazenby, J., \& Herron, M. (1996). Assessing the Work Environment for Creativity. The Academy of Management Journal, 39(5), 1154-1184. https://doi.org/10.2307/256995

Anderson, N. R., \& King, N. (1993). Innovation in Organizations. In C.L.Cooper and I.T.Robertson (Eds.).International review of Industrial and Organizational Psychology. (pp.1-34). Chichester,England: Wiley

Arı, R. (1989). Üniversite ögrencilerinin baskın ben durumları ile bazı özlük niteliklerinin ben durumlarına, atılganlık ve uyum düzeylerine etkisi. (Unpublished doctoral dissertation). Hacettepe University, Ankara.

Armstrong, D. G., Henson, K. T., \& Savage, T. V. (1997). Teaching today: An introduction to education. Toronto, Canada: Merrill/Prentice Hall.

Aslan, H., \& Kesik, F. (2016). Yenilikçi Okul Ölçeğinin Geliştirilmesi: Geçerlik ve Güvenirlik Çalışması. Educational Administration in Theory and Practice, 22(4), 463-482.

Aslaner, E. (2010). Örgütsel değişim ve yenilikçilik: bir özel okul örneği (Unpublished master's thesis) Ankara University, Ankara.

Aydın, Ö., \& Şahin, S. (2016). İlk ve ortaokul öğretmenlerinin örgütsel değişime dirençleri. Journal of Human Sciences, 13(3), 5053-5068. https://doi.org/10.14687/jhs.v13i3.3938

Bass, B. M., \& Riggio, R. E. (2006). Transformational leadership. Mahwah, NJ: Lawrence Erlbaum.

Beycioğlu, K. (2004). Illköğretim Okullarında Yenileşme Gereksinimi. (Unpublished Master’s Thesis) İnönü University, Malatya.

Çakır, B. S. (2009). İlköğretim Okullarındaki Yönetici ve Öğretmenlerin Örgütsel Değişme Ve Örgütsel Değişime Direnme Olgularını Algılamaları Üzerine Bir Araştırma. (Unpublished Master’s Thesis) Selçuk University, Konya.

Canl1, S., DemirtaŞ, H., \& Özer, N. (2015). School Administrators' Tendencies towards Change. Elementary Education Online, 14(2), 634-646.

Cemaloğlu, N. (1999). Eğitimde yeniliklerin uygulanmasinı etkileyen faktörler analizi: MLO örneği (Unpublished doctoral dissertation), Gazi University, Ankara.

Chiaroni, D, Chiesa, V., \& Frattini, F. (2011). The Open Innovation Journey: How Firms Dynamically Implement the Emerging Innovation Management Paradigm, Technovation, 31(1), 34-43. 
https://doi.org/10.1016/j.technovation.2009.08.007

Çokluk, Ö., Şekercioğlu, G., \& Büyüköztürk, Ş. (2012). Sosyal bilimler için çok değişkenli istatistik: SPSS ve LISREL uygulamaları. Ankara: Pegem A.

COM (2006). Putting knowledge into practice: A broad-based innovation strategy for the EU. 502 Final. Retrieved from http://www.insme.org/files/2283/view on 30/03/2018

Corwin, R. G. (1975). Innovation in organizations: The case of schools. Sociology of Education, 48(1), 1-37. https://doi.org/10.2307/2112048

Daft, R., \& Becker, S. (1978). Innovation in Organizations. New York: Elsevier.

Daly, A. J. (2009). Rigid response in an age of accountability: The potential of leadership and trust. Educational Administration Quarterly, 45(2), 168-216. https://doi.org/10.1177/0013161X08330499

Damanpour, F., \& Evan, W. M. (1984). Organizational innovation and performance: the problem of organizational lag. Administrative Science Quarterly, 29, 392-402. https://doi.org/10.2307/2393031

DeCanio, S. J., Dibble, C., \& Amir-Atefi, K. (2000). The Importance of Organizational Structure for the Adoption of Innovations. Management Science, 46(10), 1285-1299. https://doi.org/10.1287/mnsc.46.10.1285.12270

Demirtaş, H. (2012). Primary Schools' Openness to Change. Elementary Education Online, 11(1), 18-34.

Dibbon, D. C., \& Pollock, K. (2007). The Nature of Change and Innovation in Five Innovative Schools. The Innovation Journal: The Public Sector Innovation Journal, 12(1),1-15.

Edwards, J. L, Green K., \& Lyons, C. A. (2002). Personal empowerment, efficacy, and environmental characteristics. Journal of Educational Administration, 40(1), 67-86. https://doi.org/10.1108/09578230210415652

Ekvall, G. (1996). Organizational climate for creativity and innovation. European Journal of Work and Organizational Psychology, 5, 105-123. https://doi.org/10.1080/13594329608414845

Foster, M. (1993). Urban African American Teachers "Views of Organizational Change: Speculations on the Experiences of Exemplary Teachers, Equity and Exellence in Education, 26(3), 16-24. https://doi.org/10.1080/1066568930260304

Fullan, M. (1988). Change Processes in Secondary Schools: Towards a More Fundamental Agenda. Unpublished document, University of Toronto, Canada.

Fullan, M. (2001). The New Meaning of Educational Change. New York: Teachers College Press.

Fullan, M. (2002). The role of leadership in the promotion of knowledge management in schools. Teachers and Teaching: theory and practice, 8(3), 409-419. https://doi.org/10.1080/135406002100000530

García-Morales, V. J., Jiménez-Barrionuevo, M. M., \& Gutiérrez-Gutiérrez, L. (2012). Transformational leadership influence on organizational performance through organizational learning and innovation. Journal of Business Research, 65(7), 1040-1050 https://doi.org/10.1016/j.jbusres.2011.03.005

Geijsel, F. P. (2001). Schools and innovations. Conditions fostering the implementation of educational innovations. Nijmegen, the Netherlands: Nijmegen University

Geijsel, F. P., Van den Berg, R., \& Sleegers, P. J. C. (1999). The innovative capacity of schools in primary education: A qualitative study. International Journal of Qualitative Studies in Education, 12(2), 175-191. https://doi.org/10.1080/095183999236240

Glantz, J. E. (1998). School Restructuring Practices and Teacher Attitudes Toward Change. (Unpublished Dissertation) The Pennsylvania State University, Pennsylvania.

Gülşen, C., \& Gökyer, N. (2010). Illköğretimde yeniliklerin uygulanmasını etkileyen olası etkenler. Paper presented at the Ninth National Classroom Teaching Education Symposium, Firat University, Elazı̆g.

Hall, G. E., \& Hord, S. M. (1987). Change in schools. Facilitating the process. Albany: State University of New York Press.

Harris, A., Day, C., Hopkins, D., Hadfield, M., Hargreaves, A., \& Chapman, C. (2003). Effective Leadership for School Improvement. New York : RoutledgeFalmer.

Hatipler, D. (2014). Illköğretim okullarında görev yapan öğretmenlerin örgütsel değişme ve yenileşmeye ilişkin görüşleri (Unpublished master's thesis). Trakya University, Edirne.

Heck, R. H., \& Marcoulides, G. A. (1996). School Culture and Performance: Testing the Invariance of an 
Organizational Model. School Effectiveness and School Improvement, 7(1), 76-95. https://doi.org/10.1080/0924345960070104

Hockley, A. (2009). Managing innovation in educational organisations. Paper presented at the 9th international conference of QUEST. Romania, Iasi. Retrieved from

http://qualitraining2.ecml.at/LinkClick.aspx?fileticket=tr54FKZZrO0\%3D\&tabid=2228\&language=en-GB

İnandı, Y. (1999). Resmi ilköğretim okullarında çalışan müdür ve öğretmen görüşlerine göre ilköğretim okullarının yenileşme ihtiyaçları nelerdir? (Unpublished master's thesis) Yıldız Teknik University, İstanbul.

Jansen, J. J. P., Vera, D., \& Crossan, M. (2009). Strategic leadership for exploration and exploitation: The moderating role of environmental dynamism. The Leadership Quarterly, 20(1), 5-18.

https://doi.org/10.1016/j.leaqua.2008.11.008

Ji, H. S., Woocheol, K. D. S. C., \& Sang, H. B. (2014). The impact of an innovative school climate on teachers' knowledge creation activities in Korean schools: The mediating role of teachers' knowledge sharing and work engagement KEDI Journal of Educational Policy, 11(2), 179-203.

Jung, D. I. (2001). Transformational and Transactional Leadership and their Effects on Creativity in Groups. Creativity Research Journal, 13(2), 185-195. https://doi.org/10.1207/S15326934CRJ1302_6

Jung, D. I., Chow, C., \& Wu, A. (2003). The role transformational leadership in enhancing organizational innovation: Hypotheses and some preliminary findings. Leadership Quarterly, 14, 525-544.

https://doi.org/10.1016/S1048-9843(03)00050-X

Karasar, N. (2007). Bilimsel araştırma yöntemi. Ankara: Nobel.

Karip, E. (1997). Eğitimde yeniliklerin uygulanmasını etkileyen etkenler. Eğitim Yönetimi Dergisi, 3(1), 63-82.

Kayasandık, A. E. (2017). Öğretmenlerin Bireysel Yenilikçilik ve Değişime Hazır Olmalarının Algılanan Örgütsel Destek ile İlişkisi: Samsun'da Bir Çalışma. The Journal of Academic Social Science, 5(54), 511-527. https://doi.org/10.16992/ASOS.12792

Ketelaar, E., Beijaard, D., Boshuizen, H. P. A., \& Den, B., J. P. (2012). Teachers' positioning towards an educational innovation in the light of ownership, sense-making and agency. Teaching and Teacher Education, 28(2), 273-282. https://doi.org/10.1016/j.tate.2011.10.004

Kondakçı, Y., Zayim, M., \& Çalışkan, Ö. (2010). Investigating School Administrators' Readiness to Change in Relation to Teaching Level of the School, Experiences of the Administrators, and the Size of the School. Inonu University Journal of the Faculty of Education, 11(2), 155-175.

Korkut, M. (2009). İlköğretim Okullarında Görev Yapan Öğretmenlerin Örgütsel Değişmeye İlişkin Görüşleri: Çanakkale İli Örneği. (Unpublished Master's Thesis). Çanakkale On Sekiz Mart University, Çanakkale.

Kurşunoğlu, A., \& Tanrı̈̆ğen, A. (2006). İlköğretim Okulu Öğretmenlerinin Örgütsel Değişmeye İlişkin Tutumları. Pamukkale University Journal of the Faculty of Education, 20(2), 21-33.

Lee, J., Min, J., \& Lee, H. (2016). The Effect of Organizational Structure on Open Innovation: A Quadratic Equation Information Technology and Quantitative Management Procedia Computer Science, 91, 492-501.

Maslowski, R. (2001). School Culture and School Performance: An Explorative Study into the Organizational Culture of Secondary Schools and Their Effects. Twente University Press, Twente, the Netherlands.

McGrath, C., \& Krackhardt, D. (2003). Network conditions for organizational change. Journal of Applied Behavioral Science, 39(3), 324-336. https://doi.org/10.1177/0021886303258267

McLean, L. D. (2005). Organizational Culture's Influence on Creativity and Innovation: A Review of the Literature and Implications for Human Resource Development. Advances in Developing Human Resources. 7(2), 226-246. https://doi.org/10.1177/1523422305274528

Mercer, K. (1983). Organization Structure as a Factor in Innovation: A review of Literature. Journal of Technology, 7(2), 15-20. https://doi.org/10.1007/BF02620776

Montes, F., Moreno, J. L., Antonia, R., \& Fernandez, L. M. M. (2004). Assessing the Organizational Climate and Contractual Relationship for Perceptions of Support for Innovation. International Journal of Manpower, 25(2), 167-180. https://doi.org/10.1108/01437720410535972

Moolenaar, N. M., Daly, A. J., \& Sleegers, P. J. C. (2010). Occupying the Principal Position: Examining Relationships Between Transformational Leadership, Social Network Position, and Schools' Innovative Climate. Educational Administration Quarterly, 46(5), 623-670. https://doi.org/10.1177/0013161X10378689 
Moolenaar, N. M., Sleegers, P. J. C., \& Daly, A. J. (2011). Ties With Potential: Social Network Structure and Innovative Climate in Dutch Schools. Teachers College Record, 113(9), 1983-2017.

Mumford, M. D., Scott, G. M., Gaddis, B., \& Strange, J. M. (2002). Leading creative people: Orchestrating expertise and relationships. Leadership Quarterly, 13(6), 705-750. https://doi.org/10.1016/S1048-9843(02)00158-3

Özata, H. (2007). Öğretmenlerin Öz-yeterlik Algllarının ve Örgütsel Yenileşmeye İlişkin Görüşlerinin Araştırılması. (Unpublished Master's Thesis) Kocaeli University, Kocaeli.

Özdemir, S. (1995). Ĕgitimde Örgütsel Yenileşme, Ankara: Nobel Yayınları.

Özdemir, S., \& Cemaloğlu, N. (1999). Eğitimde Değişimi Uygulama Modelleri. Educational Administration in Theory and Practice, 5(1), 91-103.

Palmer, C. (1993). İnnovation and the experienced teacher. ELT Journal, 47(2), 166-171. https://doi.org/10.1093/elt/47.2.166

Panuwatwanich, K., Stewart, R., \& Mohamed, S. (2008). The role of climate for innovation in enhancing business performance: the case of design firms. Engineering, Construction and Architectural Management 15(5), 407-422. https://doi.org/10.1108/09699980810902712

Patton, M. Q. (1990). Qualitative evaluation and research methods. Beverly Hills CA: Sage.

Prew, M. (2007). Successful principals: why some principals succeed and others struggle when faced with innovation and transformation. South African Journal of Education, 27(3), 447-462.

Sağnak, M. (2012). The empowering leadership and teachers' innovative behavior: The mediating role of innovation climate. African Journal of Business Management, 6(4), 1635-1641.

Salaria, N. (2012). Meaning of the term- descriptive survey research method. International Journal of Transformation in Business Management, 1(6). Retrieved from http://ijtbm.com/images/short_pdf/Apr_2012_NEERU\%20SALARIA\%202.pdf

Sarason, S. (1996). Revisiting "the culture of the school and the problem of change. New York: Teachers College Press.

Sarros, J. C., Cooper. B. K., \& Santora, J. C. (2008). Building a Climate for Innovation Through Transformational Leadership and Organizational Culture. Journal of Leadership \& Organizational Studies, 15(2), 145-158. https://doi.org/10.1177/1548051808324100

Scott, S., Bruce, G., \& Reginald, A. (1994). Determinants of innovative behavior: A path model of individual innovation in the workplace, Academy of Management Journal, 27(3), 580-607. https://doi.org/10.2307/256701

Seymour, D. T. (1988). Developing Academic Programs: The Climate for Innovation. ASHE/ERIC Higher Education Report No. 3. Washington, DC: The ERIC Clearinghouse.

Shalley, C. E., \& Gilson, L. L. (2004). What leaders need to know: A review of social and contextual factors that can foster or hinder creativity. Leadership Quarterly, 15(1), 33-53. https://doi.org/10.1016/j.leaqua.2003.12.004

Sharma, R. (2001). Innovation in Schools: Identifying a Framework for Initiating, Sustaining and Managing Them. Paper presented at the Annual Meeting of the American Educational Research Association Seattle, Washington.

Siegel, S. M., \& Kaemmerer, W. F. (1978). Measuring the perceived support for innovation in organizations. Journal of Applied Psychology, 63(5), 553-562. https://doi.org/10.1037/0021-9010.63.5.553

Tanıt, N. A. (2003). Örgütsel Yenileşmede Öğretmen Tutumlarının Etkisi. (Unpublished master's thesis) Kırıkkale University, Kırıkkale.

Taş, S. (2007). Eğitimde yenileşmenin önündeki engeller. Süleyman Demirel Üniversitesi Sosyal Bilimler Dergisi, 17, 183-192.

Tenkasi, R. V., \& Chesmore, M. C. (2003). Social networks and planned organizational change. Journal of Applied Behavioral Science, 39, 281-300. https://doi.org/10.1177/0021886303258338

Van de Ven, A. H., \& Angle, H. L. (1989). An introduction to the Minnesota innovation research program. In A. H. Van de Ven, H. L. Angle, \&M. S. Poole (Eds.), Research on the management of innovation (pp. 3-30). New York: Harper \& Row.

Van de Ven, A. H., \& Rogers, E. M. (1988). Innovations and Organizations-CriticalPerspectives. Communication Research, 15, 632-651 https://doi.org/10.1177/009365088015005007

Van den Berg, R., \& Sleegers, P. J. C. (1996). Building innovative capacity and leadership. In K. Leithwood, J. Chapman, D. Corson, P. Hallinger, \& A. Hart (Eds.), International handbook of educational leadership and 
administration (pp. 653-699). London, UK: Kluwer Academic https://doi.org/10.1007/978-94-009-1573-2_20

Van Veen, K., \& Sleegers, P. (2006). How does it feel? Teachers' emotions in a context of change. Journal of Curriculum Studies, 38(1), 85-111. https://doi.org/10.1080/00220270500109304

Watt, D. (2002). How innovation occurs in high schools within the network of innovative schools: The four pillars of innovation research project. The Conference Board of Canada. Retrieved from http://www.bishops.k12.nf.ca/poster2004/fourpillars.pdf

Yılmaz, E., \& Sünbül, A. M. (2009). Developing Scale Of University Students Entrepreneurship. Selçuk University The Journal of Institute of Social Sciences, 21, 195-203.

Zaltman, G., \& Duncan, R. (1977). Strategies for Planned Change. New York: John Wiley \& Sons.

Zaltman, G., Duncan, R., \& Holbek, J. (1973). Innovations and Organizations. NewYork: John Wiley and Sons.

\section{Copyrights}

Copyright for this article is retained by the author(s), with first publication rights granted to the journal.

This is an open-access article distributed under the terms and conditions of the Creative Commons Attribution license which permits unrestricted use, distribution, and reproduction in any medium, provided the original work is properly cited. 